\title{
ALÍVIO PARA PREFEITOS COMPROMETE RESPONSABILIDADE FISCAL
}

Coluna publicada em 11.12.2018: <https://www.conjur.com.br/2018-dez-11/ contas-vista-alivio-prefeitos-compromete-responsabilidade-fiscal>

No último dia 5 de dezembro a Câmara dos Deputados aprovou projeto de lei ${ }^{1}$ que modifica a Lei de Responsabilidade Fiscal (LRF), permitindo que municípios "estourem" o limite de gastos com pessoal sem sofrer punições, caso ocorra queda na receita. ${ }^{2}$

Como é sabido, a LRF, publicada em 2000, revolucionou as finanças públicas brasileiras ao trazer normas rígidas contra o descontrole das contas públicas, estabelecendo vedações para gastos irresponsáveis e trazendo punições para os gestores. Um marco para o Direito Financeiro, a partir do qual suas normas passaram a assumir uma dimensão de importância nunca antes vista.

Mas somente agora, no início desta década, com o aprofundamento da crise financeira que se abateu sobre o país, a falta de recursos começou a testar a solidez de seus dispositivos.

Passou no primeiro e talvez mais importante teste, quando a contabilidade criativa das "pedaladas fiscais" e outras violações foram severamente punidas com o afastamento da Presidente Dilma Roussef.

Os ataques não pararam por aí. Pressões de estados falidos levaram à decretação de inusitados "estados de calamidade financeira", e criaram o regime de recu-

1 PLS 316-2015; PLP 270-2016.

2 Câmara aprova fim de punição para municípios que estourarem limite de gasto com pessoal, Folha de S.Paulo, 5 de dezembro de 2018 (https://www1.folha.uol.com.br/mercado/2018/12/ camara-aprova-fim-de-punicao-para-municipios-que-estourarem-limite-de-gasto-com-pessoal.shtml); Câmara aprova permissão para municípios estourarem limite de gastos com pessoal. Portal G1 - Globo (https://g1.globo.com/politica/noticia/2018/12/05/camara-aprova-texto-que-permite-municipios-estourarem-limite-de-gastos-com-pessoal.ghtml). 
peração fiscal, flexibilizando seus dispositivos para situações emergenciais e excepcionais. Deu-se um fôlego para evitar a falência de entes da federação que, após anos sofrendo com a queda de receitas, e aplicando técnicas de contabilidade criativa, contaram com a leniência de todo um sistema de fiscalização financeira para atingirem patamares de descontrole das contas públicas que não teriam sido possíveis se a lei estivesse sendo cumprida. ${ }^{3}$

Mas eles não cessam. É uma guerra. A LRF vive sob ataque há anos. Seus inimigos espalham-se pelas administrações públicas de todo o País, armados com suas canetas gastadoras prontas para qualquer descuido ou brecha existente.

Agora, surge mais essa verdadeira "bomba" que lhe é direcionada, na qual os prefeitos, por meio do mencionado projeto de lei recém-aprovado, como noticiado, pretendem se ver livres de punições por excesso de gastos com pessoal, caso tenham quedas importantes de arrecadação.

Com isso, conseguem uma flexibilização nas possibilidades de punição por descumprimento da LRF, que prevê, em seu art. 23, caso ultrapassado o limite previsto para os gastos com pessoal (60\% da receita corrente líquida, no caso dos municípios - LRF, art. 19, III), a proibição de receber transferências voluntárias, a vedação para receber garantias de outros entes, ficando, ainda, impedidos de contratar operaçóes de crédito.

Pela alteração proposta, e agora aprovada pelo Congresso, essas restrições não se aplicam caso se constate queda da receita superior a $10 \%$ em decorrência de diminuição das transferências recebidas pelo Fundo de Participação dos Municípios e dos repasses oriundos de royalties e participações especiais.

Vê-se, de certa forma, uma positivação generalizadora em nosso ordenamento jurídico de tese até aqui aplicada pelo STF em alguns casos restritos, por meio do chamado "princípio da intranscendência subjetiva das sanções financeiras". Nossa Suprema Corte, com fundamento na impossibilidade de fazer a pena passar da pessoa do condenado, tem entendido pela inaplicabilidade de "severas sanções às administrações por ato de gestão anterior à assunção dos deveres públicos”, com a finalidade de "neutralizar a ocorrência de risco que possa comprometer, de modo grave e/ou irreversível, a continuidade da execução de políticas públicas ou a prestação de serviços essenciais à coletividade" (STF, ACO 1393, rel. Min Luiz Fux, j. 9.6.2015). Com isto, deixam de ser punidos os gestores e entes da federação por atos realizados em administrações anteriores.

3 Crise leva as finanças públicas ao "estado de calamidade", nesta edição, p. 439-442, e Um salve pela recuperação financeira do Estado do Rio de Janeiro!, nesta edição, p. 449-454. 
É compreensível a apreensão do gestor honesto e diligente que, assumindo o mandato, desespera-se ante uma situação de caos financeiro, sobre a qual não teve responsabilidade, uma vez que herdou das gestôes anteriores. Ansioso por atender as necessidades públicas urgentes da sociedade, vê-se de mãos atadas pela total impossibilidade financeira, normalmente decorrentes de sucessivas administrações que agiram irresponsavelmente e implodiram as finanças públicas. Recebe uma situação de terra arrasada e dela não consegue se desvencilhar, dadas as inúmeras restrições a que está sujeito.

Como já mencionado neste mesmo espaço, o que se vê é decorrência do velho provérbio "em casa onde falta pão, todos brigam e ninguém tem razão". ${ }^{4}$

Sim, pois a flexibilização das puniçôes, quer sejam as pessoais aplicáveis aos gestores, quer as institucionais, que atingem os entes da federação, podendo ser elas decorrentes de alterações na legislação, ou de interpretações dos tribunais, produzem o mesmo resultado: provocam feridas na Lei de Responsabilidade Fiscal e abalam sua estrutura. E isso não traz resultados positivos para o País. Faz-se uma escolha que privilegia situações pontuais e imediatas em detrimento de uma estabilidade longa e duradoura das finanças públicas.

Os prejuízos com a adoção de medidas lenientes como essa promovem distorções indesejáveis, como o risco moral (ou moral hazard, para usar o original da expressão em inglês), uma vez que será transmitida a mensagem de que os gestores irresponsáveis foram novamente beneficiados, enquanto os que agiram responsavelmente vão, de alguma forma, acabar pagando a conta; o que não é nada positivo como exemplo para o futuro, e leva a uma indução ao mau comportamento fiscal. ${ }^{5}$

É sempre bom lembrar que a crise é geral, mas só alguns estão em situação de caos financeiro. Outros fizeram sua parte, e não é justo nem razoável que arquem com a irresponsabilidade fiscal dos demais.

Recorde-se ainda que a legislação prevê os mecanismos para ajustar as contas. O próprio art. 23 da Lei de Responsabilidade Fiscal, cuja alteração está em curso, bem como o art. 22, contém os instrumentos para o ajuste fiscal decorrente da ultrapassagem dos limites para gastos com pessoal. Não concessão de vantagens, aumentos e reajustes salariais; não provimento de cargos públicos; não contratação de horas extras; extinção de cargos e funções; e redução temporária

Em casa onde falta pão, todos brigam e ninguém tem razão, nesta edição, p. 473-478.

5 Nesse sentido, bem colocada a "Nota à imprensa sobre a alteração da LRF", emitida pela AudTCU (Associação da Auditoria de Controle Externo do TCU), lançada em 5 de dezembro de 2018, firmada pela sua Presidente Lucieni Pereira. 
de jornada de trabalho, sem prejuízo de outros que possam ser adotados. Mas essas são medidas que nenhum gestor quer tomar. Descumprem a legislação, esperam o caos financeiro se implantar, e depois aguardam que outros paguem a conta da sua irresponsabilidade.

A "nota pública" da AMPCON foi bastante precisa em definir a situação promovida pelo referido projeto de lei: "Normas de responsabilidade fiscal nas finanças públicas servem para prevenir a irresponsabilidade de gestores e devem ser cumpridas e não flexibilizadas. Se é verdade que há muitos municípios em dificuldades financeiras, também é verdade que muitos estão saneados e cumprindo fielmente a legislação. O projeto de lei em questão premia os imprevidentes e incentiva os que estão cumprindo a lei a afrouxarem seus controles. Da mesma forma, certamente, se pretenderá, em momento seguinte, que governadores que violaram a LRF também não sejam responsabilizados e que seus estados sejam tratados da mesma maneira que aqueles bem geridos."

O caos financeiro que se instalou em vários entes da federação é uma demonstração de como as contas públicas ainda não são tratadas com a seriedade que merecem. Medidas como essa lei, que fomentam a leniência no trato com as finanças públicas, não colaboram para a mudança dessa situação. E tornam cada vez mais difícil convencer a todos de que se deve levar o Direito Financeiro a sério.

6 AMPCON - Associação Nacional do Ministério Público de Contas, Nota Pública, emitida em 6 de dezembro de 2018, firmada por seu Presidente Júlio Marcelo de Oliveira. 